\title{
Chemometric evaluation of concentrations of trace elements in intervertebral disc tissue in patient with degenerative disc disease
}

\author{
Łukasz Kubaszewski ${ }^{1,2}$, Anetta Zioła-Frankowska ${ }^{3}$, Zuzanna Gasik ${ }^{4}$, Marcin Frankowski \\ Mikołaj Dąbrowski ${ }^{5}$, Bartłomiej Molisak', Jacek Kaczmarczyk ${ }^{1}$, Robert Gasik ${ }^{4}$ \\ ${ }^{1}$ Department of Orthopaedic and Traumatology, W. Dega University Hospital, University of Medical Sciences, Poznań, \\ Poland and Clinic \\ 2 Polyclinic of Neuroorthopedic and Neurology, Institute of Rheumatology, Warsaw, Poland \\ ${ }^{3}$ Faculty of Chemistry, Adam Mickiewicz University in Poznań, Poland \\ ${ }^{4}$ Clinic and Polyclinic of Neuro-orthopedic and Neurology, Institute of Rheumatology, Warsaw, Poland \\ ${ }^{5}$ Department of Spondyloorthopaedics and Biomechanics of the Spine, Poznań University of Medical Sciences, Poland
}

Kubaszewski Ł, Zioła-Frankowska A, Gasik Z, Frankowski M, Dąbrowski M, Molisak B, Kaczmarczyk J, Gasik R. Chemometric evaluation of concentrations of trace elements in intervertebral disc tissue in patient with degenerative disc disease. Ann Agric Environ Med. 2017; 24(4): 610-617. doi: 10.5604/12321966.1232555

\begin{abstract}
Background. The work is designed to uncover the pattern of mutual relation among trace elements and epidemiological data in the degenerated intervertebral disk tissue in humans. Hitherto the reason of the degenerative process is not fully understood. Trace elements are the basic components of the biological compound related both its metabolism as well as environmental exposure. The relation pattern among elements occurs gives new perspective in solving the cause of the disease.

Methods. We have analysed trace elements content in the 30 intervertebral disc from 22 patients with degenerative disc disease. The concentrations of $\mathrm{Al}, \mathrm{Cu}, \mathrm{Cd}, \mathrm{Mo}, \mathrm{Ni}$ and $\mathrm{Pb}$ were determined with Atomic Absorption Spectrometry. To analyse the multidimentional relation between trace element concentration and epidemiological data the chemometric analysis was applied.

Results. The similarity have been shown in occurrence of following pairs: Cd-Mo as well as Mg-Zn. The second pair was correlated with $\mathrm{Pb}$ concentration. Pb levels are observed to be competitive to $\mathrm{Cu}$ concentration. Cd concentration was related to $\mathrm{Zn}$ and $\mathrm{Mg}$ deficiency. No single but rather cluster of epidemiological data show observable influence on the TE tissue variance. $\mathrm{Zn}$ and $\mathrm{Cu}$ was related to the male sex. Operation with orthopedic implants were related to combined $\mathrm{Al}$, Mo and $\mathrm{Zn}$ concentration.

Conclusions. This is the first chemometric analysis of trace elements in disk tissue. It shows multidimentional relations that are missed by the classical statistic. The analysis shows significant relation. The nature of the relations is the basis for further metabolic and environmental research.
\end{abstract}

Key words

Intervertebral Disk, degeneration, trace elements, chemometrics

\section{INTRODUCTION}

Degeneration disc disease (DDD) is the most common cause of the back pain with significant impact on the health and economic issues of society in developed countries [1]. Developmental transformation of the intervertebral disc (IVD) causes loss of vascularity within the first decade of life [2]. This is followed by the transformation of metabolism that has to withstand low oxygen concentration and a highly acidic environment due to waste product concentration. The IVD structure is characterized by a large amount of extra cellular matrix (ECM) seeded with a low density of chondrorcite-like cell clusters responsible for the production and control of the matrix turnover. Highly hydrophilic ECM proprieties allow water retention and ensure the biomechanical proprieties of the IVD.

Address for correspondence: Łukasz Kubaszewski, Department of Orthopaedic and Traumatology, W. Dega University Hospital, University of Medical Sciences, Poznań, Poland

E-mail: eklinika@o2.pl

Received: 25 January 2014; accepted: 2 September 2014; first published on February 2017
Trace element (TE) in human biochemistry are divided in three groups with regard to their metabolic role: essential, possible essential and non-essential [3]. TE, due to their small quantity in biota, may be regarded as a specific indicators for both metabolic or environmental factors. The metabolic indicators of TE contents fluctuation can be analyzed in terms of the degeneration process. Degenerative disc disease is a complex and not fully understood entity. For an explanation, a number of theories have been proposed, including: aging, genetic and environmental factors. It has been proved that an important role in degeneration process is influence by the disproportion of anabolic and catabolic activity of the ECM enzymes, such as cathepsins, aggrecanases, and matrix metalloproteinases (MMPs) [4]. The MMPs enzymes are zincrelated endopeptidase, the major role of which is protein degradation. TE also have the ability to form other bio-active compounds [5]. They are part of enzymes, or are involved in collagen synthesis, while others are essential for connective tissue development [6].

TE analysis in the IVD may be suitable for several reasons. Since IVD may be considered as the most inert compartment 
in human, cross-reference analysis with other tissues, for example, bone, may be more accurate in predicting the timing and dose of environmental exposure. Additionally, it can improve our knowledge of end plate function and its possible role in DDD. Understanding the mutual relationship of the metabolic related $\mathrm{TE}(\mathrm{Mg}, \mathrm{Zn}, \mathrm{Cu})$ will also change our knowledge of senescence and the degeneration processes [3].

Perception of the measurement of biological samples is the domain of multivariate analysis. The chemometric approach more thoroughly explores large sets of data or data that cannot be compared, or their relation may not be detected with basic statistics. Chemometric analysis was developed as the consequence of modern chemical analysis [7], and allows uncovering the hidden relationships within the multi-dimensional data matrix in the form of a numerical algorithm.

In available studies there are none which contain chemometric analysis of TE in intervertebral disc tissue. Such analysis was utilized by Brodziak et al. [8] in bone tissue, although in this analysis only Euclidian's distances method was used, it supports the hypothesis of the authors of the presented study concerning the usefulness of chemometric methods, especially in research at the border between organic chemistry and biology with the medical implications. Overall, there are only two studies by Tohno et al. [9] and Minami et al. [10] evaluating selected elements in the IVD, although no biological implication of such analysis has so far been performed.

The main aim of the current work was to apply chemometric techniques as a useful tool for: 1) demonstrating the differences in the TE concentration in the degenerated IVD in samples; 2) discerning mutual relationships between particular TE concentrations in degenerated tissue of intervertebral discs; 3) performing the correlation of the TE concentration with particular epidemiological data.

\section{MATERIALS AND METHOD}

Material from the intervertebral discs of 22 patients were obtained during surgical procedure. Twelve specimens were from the cervical spine of six patients and 19 specimens were harvested form the lumbar spine of 18 patients. All specimens were acquired by the surgical procedure of discectomy or spine fusion, due to degenerative disc disease. The mean age of the patients during the operation was 47.6, ranging from 28-64 years of age. Use of tissue in the study was approved by the Bioethical Committee of the Institute of Rheumatology in Warsaw on 31 May 2012, and the Bioethical Committee of Poznań University of Medical Sciences (Ref. No. 406/13). All patients were interviewed using a questionnaire to collect data on demography, health status, and occupational exposure to heavy metals, or a previous operation for the implantation of an orthopedic device. In the question examination, none of the patients had any knowledge of being inadvertently exposed to heavy metal pollution. Evaluation of the degree of the degenerative disc disease was performed on preoperative MRI sagittal scans, according to the Pfirrmann grading score [11].

The frozen intervertebral disc samples were freeze-dried using a Lyovac lyophilizer GT2e (Steris, Germany) for 24 hours. After drying, the sample were weighed and nitric acid (suprapur, Merck, Germany) was added to obtain dilution factor (DF) of 10. The prepared samples were allowed to stand overnight in order to slow mineralization. The samples were then mineralized in a microwave oven (Mars Xpress 5, USA). The concentrations of trace elements were calculated for dry weight $(\mathrm{dw})$ of the disc. Concentrations of $\mathrm{Al}, \mathrm{Cd}$, $\mathrm{Mo}, \mathrm{Ni}$ and $\mathrm{Pb}$ were determined in three replications using an Atomic Absorption Spectrometer AA 7000 (Shimadzu, Japan) with graphite furnace atomisation (GF-AAS). The \% RSD for GF-AAS analytical technique did not exceed $5 \%$. The concentrations of $\mathrm{Cu}, \mathrm{Mg}$ and $\mathrm{Zn}$ were determined in three replications with the use of an Atomic Absorption Spectrometer (AA 7000, Shimadzu, Japan) with flame atomisation (F-AAS). The \% RSD for F-AAS analytical technique did not exceed $7 \%$. Table 1 presents the basic optimised parameters for the determination of $\mathrm{Al}, \mathrm{Cu}, \mathrm{Cd}$, $\mathrm{Mo}, \mathrm{Ni}, \mathrm{Pb}, \mathrm{Zn}$ and $\mathrm{Mg}$ by the AAS analytical technique.

Statistical analysis. The collected data were analyzed with the chemometric methods of pattern recognition to determine the similarity between both the TE contents and between

Table 1. Optimized parameters of analyzed TE by Atomic Absorption Spectrometry

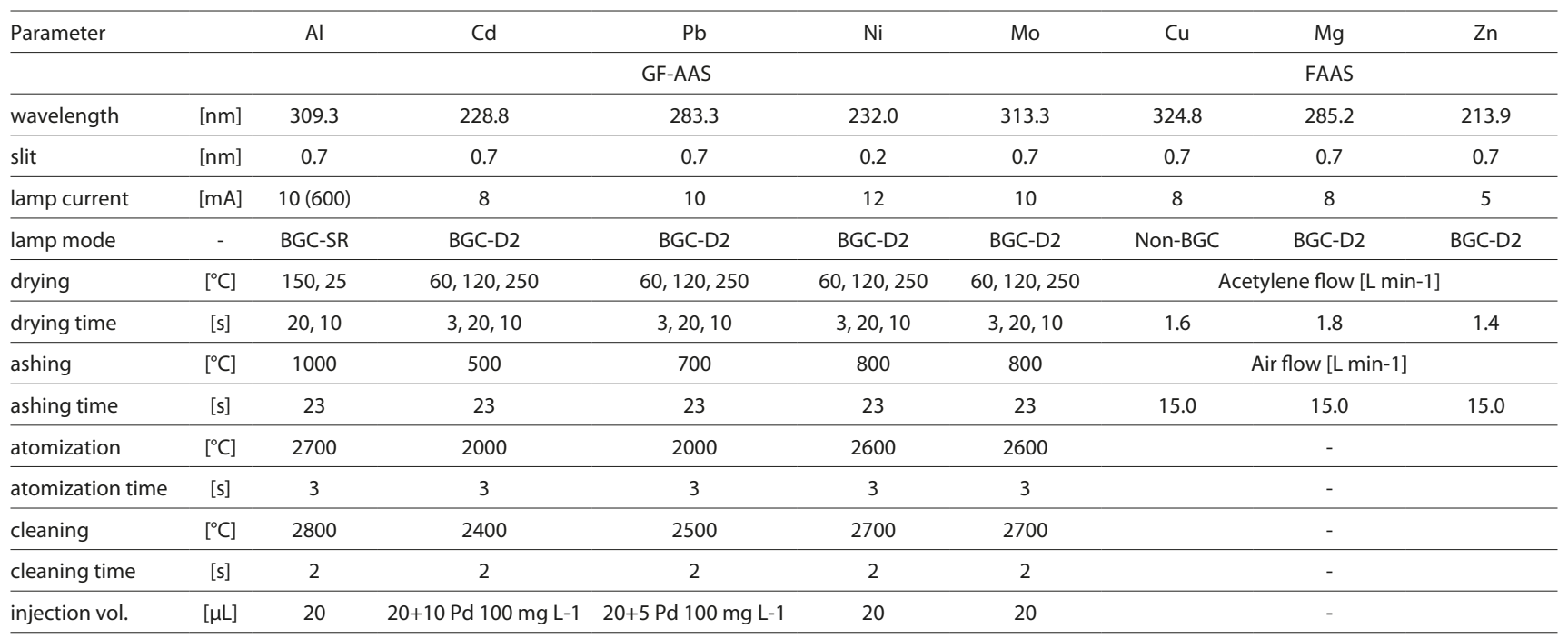


samples. After autoscaling of the data, a graph analysis for each TE pairs was performed to discern the distribution pattern. For the similarity analysis, tangent distances (dT), i.e. the absolute value of the tangent of the angle between the feature vectors [7].

$$
\mathrm{d}_{\mathrm{ij}} \mathrm{T}=\sqrt{((1-r 2) / r 2)}
$$

$r$ - angle between two vectors describing analyzed traits: i and $j$.

Similarity analysis was performed with cluster methods, Euclidean distance and dendrogram presentation. Correlation of the cluster formation in samples analysis with clinical and epidemiological data was performed. To select factors influencing the clusters, principal component analysis (PCA) was carried out for sample multivariate matrix. After determination of the principal components, new cluster analysis (CA) for samples, as well as the correlation with clinical and epidemiological data was performed. Statistica (Statsoft, Tulsa, OK) software was used for statistical analysis.

\section{RESULTS}

Results of the concentrations of TE in the IVD tissue are presented in Table 2.

In the case of Cd in 13 samples, Mo in 5 samples and $\mathrm{Ni}$ in one sample, the levels were below the level of detection (LOD). For the chemometrics analysis values of the $0.5 \mathrm{LOD}$ were substituted in such cases. Analysis of the similarities among traits - TE concentration. After autoscaling, graph analysis for two-dimensional distribution for each TE pair was drawn, which revealed the points of deviation with regard to an extraordinary high concentration of a particular element. The deviation points were evaluated in all pairs of TE. Most often, the deviation point was associated with specimen No. 24. (11 out of 21 ceases) and specimen No. 27 ( 9 out of 21 cases). These two specimens were excluded from the further similarity analysis as the potential diverging elements. Specimen No. 27 deviated mostly for a higher concentration of $\mathrm{Zn}, \mathrm{Cu}$ and $\mathrm{Mg}$, compared to the other specimens. Specimen No. 24 had a deviation point due to higher levels of Mo and Cd. In both cases, the specimens

Table 2. TE concentration in analyzed group

\begin{tabular}{|c|c|c|c|c|c|c|c|c|c|c|c|c|c|c|}
\hline $\begin{array}{l}\text { Specimen } \\
\text { No. }\end{array}$ & $\begin{array}{l}\text { Patient } \\
\text { No. }\end{array}$ & Gender & $\begin{array}{l}\text { Previous orthopedic } \\
\text { operation with implants }\end{array}$ & $\begin{array}{c}\text { Spine region } \\
\mathrm{L}-\text { lumbar } \mathrm{C}-\text { cervical }\end{array}$ & Age & $\begin{array}{l}\text { Pfirrmann } \\
\text { score }\end{array}$ & $\mathrm{Al}$ & $\mathrm{Cd}$ & $\mathrm{Pb}$ & $\mathrm{Ni}$ & Mo & $\mathrm{Cu}$ & $\mathrm{Mg}$ & $\mathrm{Zn}$ \\
\hline & & & & & & & \multicolumn{5}{|c|}{$\mu \mathrm{kg}^{-1} \mathrm{dw}$} & \multicolumn{3}{|c|}{$\mathrm{mg} \mathrm{kg}^{-1} \mathrm{dw}$} \\
\hline 1 & 1 & M & $\mathrm{N}$ & L & 49 & 2 & 539.5 & 4921 & 170.1 & 222.9 & 111.2 & 5.602 & 413.9 & 18.29 \\
\hline 2 & 2 & M & $\mathrm{N}$ & L & 47 & 2 & 1203 & 0.2 & 1264 & 134.8 & 54.35 & 2.492 & 1195 & 61.26 \\
\hline 3 & 2 & M & $\mathrm{N}$ & L & 47 & 2 & 915.1 & 9171 & 209.7 & 387.2 & 62.67 & 2.793 & 489.5 & 16.88 \\
\hline 4 & 3 & M & $\mathrm{Y}$ & c & 53 & 3 & 992.1 & 0.2 & 1252 & 369.9 & 29.38 & 2.092 & 1599 & 71.22 \\
\hline 5 & 3 & M & $\mathrm{Y}$ & C & 53 & 2 & 1084 & 0.2 & 1343 & 62.23 & 35.55 & 1.844 & 854.7 & 36.12 \\
\hline 6 & 3 & M & $\mathrm{Y}$ & c & 53 & 2 & 1021 & 0.2 & 1417 & 444.2 & 33.41 & 1.889 & 2132 & 121.75 \\
\hline 7 & 4 & M & $\mathrm{N}$ & c & 61 & 3 & 572.7 & 16.02 & 867.3 & 143.4 & 77.23 & 1.459 & 672.1 & 25.72 \\
\hline 8 & 5 & $\mathrm{~F}$ & $\mathrm{~N}$ & L & 64 & 5 & 1003 & 0.2 & 1825 & 43.22 & 1 & 0.9701 & 1622 & 29.38 \\
\hline 9 & 6 & M & Y & L & 57 & 5 & 1271 & 0.2 & 1599 & 373.4 & 38.89 & 2.317 & 1475 & 64.62 \\
\hline 10 & 7 & M & $\mathrm{N}$ & L & 38 & 3 & 451.2 & 4751 & 191.2 & 131.3 & 72.12 & 1.079 & 607.7 & 18.29 \\
\hline 11 & 8 & $\mathrm{~F}$ & $\mathrm{~N}$ & L & 28 & 3 & 539.5 & 0.2 & 61.47 & 53.58 & 1 & 1.326 & 634.8 & 12.65 \\
\hline 12 & 9 & $\mathrm{~F}$ & $\mathrm{~N}$ & L & 29 & 3 & 552.2 & 0.2 & 566.9 & 245.4 & 42.56 & 1.542 & 1008 & 38.97 \\
\hline 13 & 10 & M & $\mathrm{N}$ & L & 49 & 3 & 470.1 & 6444 & 167.3 & 213.4 & 69.82 & 1.616 & 371.4 & 14.06 \\
\hline 14 & 11 & M & $\mathrm{N}$ & L & 59 & 2 & 520.6 & 562 & 2233 & 165.9 & 21.24 & 1.664 & 1032 & 55.76 \\
\hline 15 & 11 & M & $\mathrm{N}$ & L & 47 & 2 & 697.3 & 9292 & 314.2 & 312.9 & 35.89 & 1.799 & 516.7 & 34.35 \\
\hline 16 & 12 & M & $\mathrm{N}$ & L & 39 & 2 & 490.6 & 7.64 & 665.9 & 421.2 & 43.58 & 2.046 & 977.9 & 43.84 \\
\hline 17 & 13 & M & $\mathrm{N}$ & L & 49 & 4 & 545.9 & 0.2 & 525.9 & 117.5 & 1 & 2.519 & 999.4 & 18.53 \\
\hline 18 & 14 & M & $\mathrm{N}$ & L & 47 & 2 & 440.1 & 1625 & 266.3 & 162.5 & 55.21 & 1.417 & 482.8 & 36.78 \\
\hline 19 & 15 & $\mathrm{~F}$ & $\mathrm{~N}$ & L & 55 & 3 & 444.7 & 0.2 & 589.2 & 48.15 & 73.16 & 6.089 & 856.2 & 41.18 \\
\hline 20 & 16 & $\mathrm{~F}$ & $\mathrm{~N}$ & C & 55 & 3 & 240.1 & 5634 & 495.9 & 181.2 & 62.38 & 2.715 & 368.3 & 48.51 \\
\hline 21 & 17 & $\mathrm{~F}$ & $\mathrm{~N}$ & L & 42 & 3 & 165.7 & 7595 & 198.3 & 103.3 & 53.91 & 4.562 & 246.5 & 11.35 \\
\hline 22 & 18 & $\mathrm{~F}$ & $\mathrm{~N}$ & L & 34 & 2 & 192.6 & 8.52 & 186.6 & 169.9 & 34.65 & 4.101 & 182.6 & 10.56 \\
\hline 23 & 19 & $\mathrm{~F}$ & $\mathrm{~N}$ & L & 47 & 3 & 546.6 & 13209 & 478.4 & 106.2 & 35.42 & 3.827 & 371.5 & 22.19 \\
\hline 24 & 20 & $\mathrm{~F}$ & $\mathrm{~N}$ & C & 54 & 3 & 748.9 & 24764 & 274.2 & 308.6 & 143.2 & 3.073 & 291.1 & 15.44 \\
\hline 25 & 20 & $\mathrm{~F}$ & $\mathrm{~N}$ & c & 54 & 3 & 389.2 & 6218 & 338.3 & 427.6 & 61.61 & 3.356 & 276.4 & 16.11 \\
\hline 26 & 21 & $\mathrm{~F}$ & Y & C & 49 & 3 & 461.1 & 8026 & 204.2 & 400.7 & 43.13 & 3.695 & 299.4 & 17.56 \\
\hline 27 & 21 & $\mathrm{~F}$ & Y & C & 49 & 2 & 743.2 & 0.2 & 1050 & 311.5 & 1 & 23.64 & 2016 & 184.5 \\
\hline 28 & 22 & M & Y & c & 40 & 3 & 632.9 & 0.2 & 773.2 & 1 & 1 & 2.517 & 512.5 & 37.32 \\
\hline 29 & 22 & M & Y & C & 40 & 3 & 776.8 & 0.2 & 717.6 & 158.5 & 47.75 & 4.968 & 614.3 & 35.46 \\
\hline 30 & 22 & M & Y & C & 40 & 3 & 360.6 & 9016 & 355.8 & 25.48 & 20.02 & 3.356 & 884.3 & 29.62 \\
\hline
\end{tabular}


were harvested from the patients where IVD were acquired from two different levels in cervical spine. The other sample from the same patients did not show such a deviation.

Graph analysis allowed to discern relationships between the TE pairs, and the graphs were pooled in relation to distribution pattens. Three distribution patterns were observed: uniform, non-uniform and correlated. Although this analysis may resemble the correlation analysis, it does not show all the information observed in the graphical presentation. The uniform distribution pattern refers to TE pairs where no correlation distribution could be observe with the regular scatter of the samples in the two-dimensional plane. Uniform distribution was observed in the following TE pairs: $\mathrm{Cd} / \mathrm{Ni}, \mathrm{Cd} / \mathrm{Mo}, \mathrm{Cd} / \mathrm{Cu}, \mathrm{Pb} / \mathrm{Ni}, \mathrm{Pb} / \mathrm{Mo}, \mathrm{Ni} / \mathrm{Mo}, \mathrm{Ni} / \mathrm{Mg}$, $\mathrm{Ni} / \mathrm{Zn}, \mathrm{Mo} / \mathrm{Cu}, \mathrm{Mo} / \mathrm{Zn}, \mathrm{Cu} / \mathrm{Zn}$. Non-uniform distribution showed three types of samples: 1) high concentration of one TE accompanied by low levels of the other TE; 2) vice versa; 3) was characterized by low concentrations for both TE. Non-uniform distribution was observed in the following TE pairs: $\mathrm{Cd} / \mathrm{Pb}, \mathrm{Cd} / \mathrm{Mg}, \mathrm{Cd} / \mathrm{Zn}, \mathrm{Pb} / \mathrm{Cu}, \mathrm{Ni} / \mathrm{Cu}, \mathrm{Mo} / \mathrm{Mg}, \mathrm{Cu} /$ $\mathrm{Mg}$. Figure 1 shows an example of non-uniform distribution for the $\mathrm{Cu} / \mathrm{Pb}$ pair.

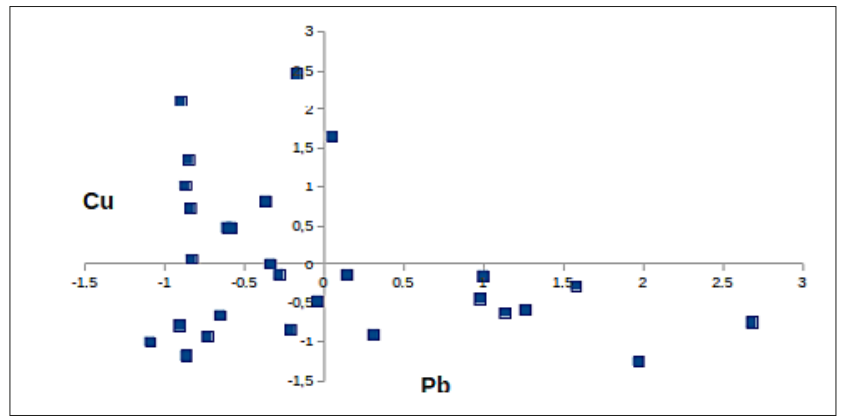

Figure 1. $\mathrm{Cu} / \mathrm{Pb}$ two dimensional distribution showing nonuniform pattern

A correlated distribution pattern was observed in three TE pairs: $\mathrm{Pb} / \mathrm{Mg}, \mathrm{Pb} / \mathrm{Zn}, \mathrm{Mg} / \mathrm{Zn}$, showing a positive correlation between both TE concentrations. Tangents distance measure is based on a common resource of information carried by the analyzed traits, and is currently the most widely-used in the analysis of similarities.

After deviation point exclusion, the matrix of tangent distances for TE was calculated. The dT values were used for dendrite graphical presentation. The dendrogram analysis for TE tangent distances is presented in Figure 2.

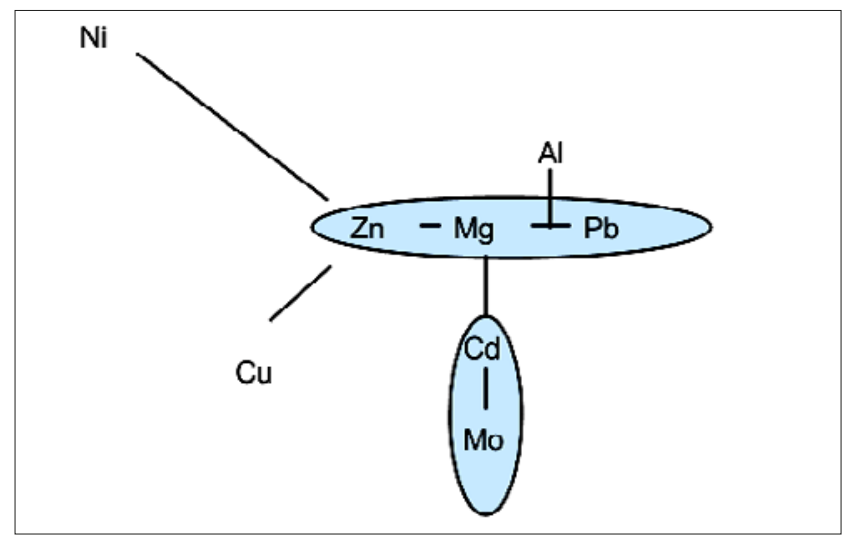

Figure 2. Graphical presentation of cluster formation based on the tangent distances

Analysis showed two major primary clusters. The first one consist of $\mathrm{Zn}, \mathrm{Mg}$ and $\mathrm{Pb}$. The dT between elements were 0.74 $\mathrm{Zn}-\mathrm{Mg}$ and 0.93 in $\mathrm{Mg}-\mathrm{Pb}$, although the $\mathrm{Zn}-\mathrm{Pb}$ distance was 1.65. The second primary cluster was $\mathrm{Cd}-\mathrm{Mo}$ with a distance of 1.3. This cluster was most proximal to $\mathrm{Mg}$ with $\mathrm{Mg}-\mathrm{Cd}$ distance of 1.58. Al is most proximal to $\mathrm{Mg}(1.22)$ and in second position to $\mathrm{Pb}(1.24)$. $\mathrm{Cu}$ was most proximal to $\mathrm{Zn}$ with the distance of 1.10, with the distances to nest TE rising sharply. Ni was the most distant branch of the dendrogram, with the least distance to $\mathrm{Zn}$ of 3.04. CA showed a similar grouping pattern observed with the dendrogram.

Further similarity analysis was performed with regards to samples. For measuring the similarity between the samples the absolute value of the tangent distances were calculated. The distances variability between the samples were smaller, comparable to the distances between the features. This may suggest that potential similarities may be hidden with the vectors oriented in opposite directions. The cluster recognition method showed similar cluster formation, both with the single-linkage and complete-linkage method. The clinical and epidemiological data were superimposed on the dendrogram for mapping them with the cluster formation. The data referred to in the analysis were: gender, region of the spine of sample collection (cervical or lumbar), prior

Table 3. Principal component analysis array. Two thresholds were taken for factor selection 0,5 and 0,75 . The values above 0,5 are bold, values above 0,75 are underlined

\begin{tabular}{|c|c|c|c|c|c|c|c|c|c|c|}
\hline & \multicolumn{10}{|c|}{ Component } \\
\hline & 1,000 & 2 & 3 & 4 & 5 & 6 & 7 & 8 & 9 & 10 \\
\hline Pfirman score & $-0,141$ & $\underline{0,761}$ & 0,000 & 0,548 & 0,000 & $-0,225$ & $-0,087$ & $-0,193$ & $-0,028$ & 0,052 \\
\hline $\mathrm{Al}$ & $-0,709$ & 0,091 & 0,000 & 0,145 & 0,000 & 0,263 & 0,031 & 0,053 & 0,135 & 0,038 \\
\hline $\mathrm{Cd}$ & 0,591 & 0,015 & 0,000 & 0,150 & 0,000 & $-0,227$ & 0,429 & 0,172 & $-0,077$ & $-0,021$ \\
\hline $\mathrm{Pb}$ & $\underline{-0,867}$ & 0,239 & 0,000 & $-0,231$ & 0,000 & $-0,066$ & $-0,092$ & 0,149 & $-0,288$ & 0,060 \\
\hline Mo & 0,524 & $-0,037$ & 0,000 & $-0,207$ & 0,000 & 0,125 & $-0,097$ & $-0,384$ & 0,000 & 0,007 \\
\hline $\mathrm{Cu}$ & 0,117 & $\underline{0,807}$ & 0,000 & $-0,110$ & 0,000 & 0,432 & 0,218 & 0,052 & 0,004 & 0,024 \\
\hline $\mathrm{Mg}$ & $-0,936$ & $-0,060$ & 0,000 & 0,101 & 0,000 & 0,051 & 0,175 & $-0,161$ & $-0,056$ & 0,000 \\
\hline $\mathrm{Zn}$ & $\underline{-0,777}$ & $-0,425$ & 0,000 & $-0,065$ & 0,000 & $-0,100$ & 0,299 & $-0,183$ & 0,060 & 0,000 \\
\hline age & $-0,408$ & 0,423 & 0,000 & $-0,304$ & 0,000 & $-0,291$ & $-0,150$ & 0,078 & 0,178 & 0,000 \\
\hline
\end{tabular}


operation with metallic implants, and samples collected form the same patient. In the mapping analysis, there was no confirmation of any correlation between given clinical or epidemiological data with cluster formation, neither with the single nor complete-linkage methods.

Considering the above principal component, analysis was performed to enhance signal-to-noise ratio of the analyzed data. This presents the opportunity to elucidate the most significant TE, clinical and epidemiological data influencing the variation of the multi-dimensional measurement space. The original analysis of principal component included all items. After transformation of the original variables into a new orthogonal array, three main components were distinguished determining the $72.09 \%$ of the total variability of the information in analyzed data set (Tab. 3).

The first component was created by the information contained in data describing the concentrations of $\mathrm{Al}, \mathrm{Cd}$, $\mathrm{Pb}, \mathrm{Mo}, \mathrm{Mg}$ and $\mathrm{Zn}$. The second component was dependent on the information contained in data describing the degree of degenerative changes according to the Pfirrmann score and copper concentration. The third component was dependent largely on the Ni concentration, and contained redundant information provided by the $\mathrm{Cd}$ concentration. It may be assumeed that all three components were not correlated with one another due to the fact that they are orthogonal to each other. However, this does not exclude the possible of correlation among elements building up the components. The absence of redundancy, with the exception of $\mathrm{Cd}$ concentration (in components one and three), allows the conclusion that each component provides unique information to the analyzed data set.

It is important to mention that the analysis of $\mathrm{Cu}$ showed a relationship with the volatility of the remaining elements. Characteristic is the link between the volatility of metabolism-related TE and those considered as toxic ( $\mathrm{Al}, \mathrm{Cd}, \mathrm{Pb}, \mathrm{Mo}, \mathrm{Mg}$ and $\mathrm{Zn}$ ), indicating the presence of biological interdependence in the intervertebral disc tissue. It is also important that these elements largely determine the variability of the analyzed data set (35.93\%). PCA graphical presentation allows the identification of several TE clusters of similar variation in the analysis (Fig. 3).

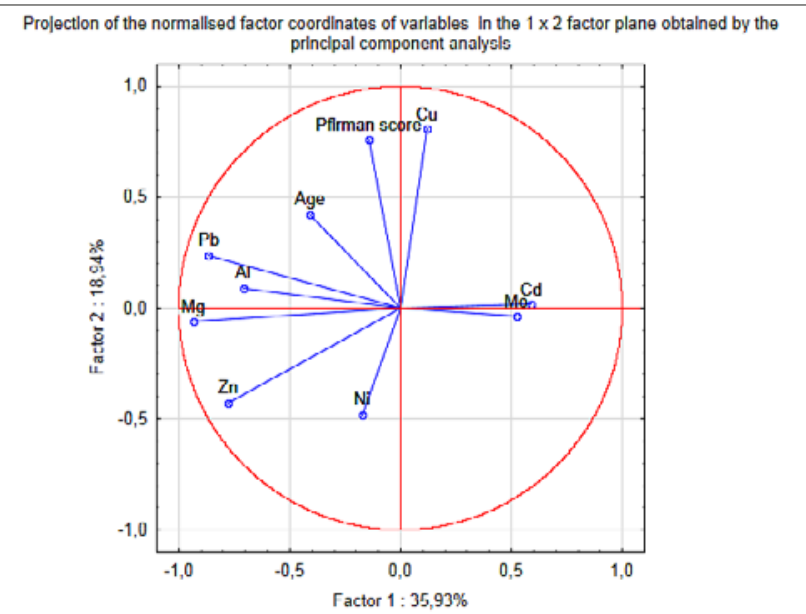

Figure 3. Graphical representation of variance distribution in two-dimensional space.

The most distinct cluster was the pair Mo and Cd. The second potential cluster describing similar variability of the analyzed data was $\mathrm{Pb}, \mathrm{Mg}$ and $\mathrm{Al}$ included in first component. It was possible to distinguish a similarity between $\mathrm{Cu}$ concentration and the degree of degeneration according to the Pfirrmann score. The rest of the factors were not recognized as showing particular similarity, based on the graph presentation of the PCA.

Analysis was performed of the PCA with respect to following data: gender, previous operations with orthopedic implants, and region of the spine where material was harvested. Results of the analysis are presented in Table 4.

In the analysis, the variability with a threshold level of 0.75 characteristic similarities can be distinguished. In all cases, noticeable similarities were observed of variation between $\mathrm{Pb}$ and $\mathrm{Mg}$. In males, a similar volatility was noticeable among $\mathrm{Cu}$ and $\mathrm{Zn}$ concentration, which was not observed in the case of females. Patients with a history of orthopedic operations with implants, presented a significant similarity of concentration between $\mathrm{Al}, \mathrm{Mo}, \mathrm{Zn}$. Also in this group of patients, age was a significant modifier. Analysis taking into account the region of the spine from which the samples were harvested, showed a noticeable Ni correlation with the lumbar spine. In the case of the cervical spine, except for the above-mentioned influence of $\mathrm{Pb}$ and $\mathrm{Mg}$, variability was observed related to the concentration of $\mathrm{Zn}$, age of the patient and severity of the degenerative changes according to Pfirrmann score.

\section{DISCUSSION}

The analyzed TE set contains: essential ( $\mathrm{Cu}, \mathrm{Mn}, \mathrm{Mo}, \mathrm{Zn}$ and $\mathrm{Mg})$, possible essential $(\mathrm{Ni}, \mathrm{Al})$ and toxic $(\mathrm{Cd}, \mathrm{Pb})[3]$.

Basic graphical analysis of TE pairs showed three types of distribution that may be regarded as the correlation patterns. The non-uniform distribution in graphical analysis may suggest competitiveness among the elements, which can be divided into three categories:

1) between both TE related to pollution, $\mathrm{Cd} / \mathrm{Pb}$;

2) between pollution and metabolic-related TE $\mathrm{Cd} / \mathrm{Mg}, \mathrm{Cd} /$ $\mathrm{Zn}, \mathrm{Pb} / \mathrm{Cu}$;

3) between both $\mathrm{TE}$ related to metabolism $\mathrm{Ni} / \mathrm{Cu}, \mathrm{Mo} / \mathrm{Mg}$, $\mathrm{Cu} / \mathrm{Mg}$.

An important antagonistic relationship was confirmed in the case of $\mathrm{Zn}-\mathrm{Cd}$ and $\mathrm{Zn}-\mathrm{Cu}$. Also, other dependencies described in the literature, both in biota and abiota, showed antagonism between $\mathrm{Mg}$ and $\mathrm{Zn}, \mathrm{Ni}, \mathrm{Cu}$, or $\mathrm{Cu}$ and Mo [3]. This set of TE $\mathrm{Zn}-\mathrm{Cd}$ and $\mathrm{Zn}-\mathrm{Cu}$ antagonisms were also recognizable with PCA graph in the presented study. Competitiveness was also observed in the graphical presentation of the $\mathrm{Mg}$-Cu pair, but in the the current study, no competitiveness in the $\mathrm{Mg}-\mathrm{Zn}$ pair was observed. The other pairs mostly showed the orthogonal position or dissimilarity with higher tangent distances. The presented findings confirm some of the literature declared antagonism while presenting others that have not been recognized so far. A distribution pattern suggesting the correlation, in graphical presentation, was observed in three pairs, formed with only three TE: $\mathrm{Mg}, \mathrm{Zn}$ and $\mathrm{Pb}$. Those elements also formed the primary cluster with dendrogram analysis. With the PCA analysis, a similar cluster was observed, although the $\mathrm{Mg}$ and $\mathrm{Pb}$ position was closer to $\mathrm{Al}$ than to $\mathrm{Zn}$. Also with PCA analysis, the $\mathrm{Mg}-\mathrm{Pb}$ pair always formed the first component 
Table 4. Principal component analysis with regard to following epidemiological differentiators: gender (a), previous orthopedic operation with implants (b), part of the spine where samples were retrieved (c). Two thresholds were taken for factor selection 0.5 and 0.75 . Values above 0.5 shown in bold, values above 0.75 are underlined

\begin{tabular}{|c|c|c|c|c|c|c|c|}
\hline Table 4a & & & & & & & \\
\hline Gender - M & component 1 & component 2 & component 3 & Gender - F & component 1 & component 2 & component 3 \\
\hline Al & $-0,703$ & 0,238 & $-0,326$ & Al & $-0,744$ & 0,097 & 0,392 \\
\hline $\mathrm{Cd}$ & 0,655 & 0,351 & 0,126 & $\mathrm{Cd}$ & 0,421 & 0,574 & 0,560 \\
\hline $\mathrm{Pb}$ & $-0,872$ & $-0,166$ & 0,065 & $\mathrm{~Pb}$ & $\underline{-0,967}$ & 0,050 & 0,127 \\
\hline $\mathrm{Ni}$ & $-0,404$ & 0,722 & $-0,007$ & $\mathrm{Ni}$ & 0,347 & $-0,140$ & 0,714 \\
\hline $\mathrm{Cu}$ & 0,288 & 0,176 & $\underline{-0,838}$ & $\mathrm{Cu}$ & $-0,515$ & 0,712 & $-0,328$ \\
\hline $\mathrm{Mg}$ & $-0,904$ & 0,079 & $-0,086$ & $\mathrm{Mg}$ & $-0,848$ & $-0,452$ & 0,202 \\
\hline $\mathrm{Zn}$ & $\underline{-0,878}$ & 0,201 & 0,005 & $\mathrm{Zn}$ & $-0,411$ & $-0,701$ & 0,494 \\
\hline Age & $-0,580$ & 0,125 & 0,224 & age & $-0,477$ & 0,552 & 0,473 \\
\hline Pfirrmann score & $-0,163$ & $-0,518$ & $-0,433$ & Pfirrmann score & $-0,642$ & 0,641 & $-0,187$ \\
\hline implants - yes & component 1 & component 2 & component 3 & implants - no & component 1 & component 2 & component 3 \\
\hline Al. & $-0,809$ & 0,480 & 0,326 & Al & $-0,488$ & 0,207 & 0,480 \\
\hline $\mathrm{Cd}$ & 0,709 & $-0,031$ & $-0,582$ & $\mathrm{Cd}$ & 0,565 & 0,606 & 0,279 \\
\hline $\mathrm{Pb}$ & $-0,902$ & 0,231 & 0,332 & $\mathrm{~Pb}$ & $\underline{0,000}$ & 0,027 & 0,302 \\
\hline $\mathrm{Ni}$ & $-0,574$ & 0,325 & $-0,689$ & $\mathrm{Ni}$ & 0,476 & $-0,044$ & 0,586 \\
\hline Mo & 0,090 & $\underline{0,877}$ & $-0,207$ & Mo & 0,556 & 0,455 & 0,456 \\
\hline $\mathrm{Cu}$ & $\underline{0,761}$ & 0,532 & 0,000 & $\mathrm{Cu}$ & -0.413 & 0.637 & $-0,27$ \\
\hline $\mathrm{Mg}$ & $-0,878$ & $-0,228$ & $-0,227$ & $\mathrm{Mg}$ & $\underline{-0,922}$ & $-0,112$ & 0,091 \\
\hline $\mathrm{Zn}$ & $\underline{-0,756}$ & $-0,526$ & $-0,239$ & $\mathrm{Zn}$ & $-0,573$ & $-0,359$ & 0,576 \\
\hline Age & $\underline{-0,790}$ & 0,412 & $-0,240$ & age & $-0,410$ & 0,650 & 0,339 \\
\hline Pfirrmann score & 0,076 & 0,650 & 0,095 & Pfirrmann score & 0,000 & 0,518 & $-0,558$ \\
\hline \multicolumn{8}{|l|}{ Table 4c } \\
\hline Al. & $-0,732$ & $-0,319$ & 0,230 & Al & $-0,678$ & 0,162 & 0,492 \\
\hline $\mathrm{Cd}$ & 0,524 & $-0,007$ & 0,605 & $\mathrm{Cd}$ & 0,657 & 0,470 & $-0,124$ \\
\hline $\mathrm{Pb}$ & $-0,902$ & $-0,061$ & 0,034 & $\mathrm{~Pb}$ & $-0,905$ & 0,000 & 0,381 \\
\hline $\mathrm{Ni}$ & 0,018 & $-0,809$ & 0,168 & $\mathrm{Ni}$ & $-0,152$ & 0,679 & $-0,489$ \\
\hline Mo & 0,426 & $-0,316$ & 0,596 & Mo & 0,580 & 0,719 & 0,260 \\
\hline $\mathrm{Cu}$ & $-0,311$ & 0,676 & 0,464 & $\mathrm{Cu}$ & 0,747 & $-0,270$ & 0,039 \\
\hline $\mathrm{Mg}$ & $-0,954$ & $-0,056$ & $-0,146$ & $\mathrm{Mg}$ & $-0,917$ & 0,061 & $-0,212$ \\
\hline $\mathrm{Zn}$ & $-0,728$ & $-0,552$ & $-0,018$ & $\mathrm{Zn}$ & $-0,853$ & 0,061 & $-0,433$ \\
\hline Age & $-0,651$ & 0,143 & 0,617 & age & $-0,110$ & $\underline{0,843}$ & 0,199 \\
\hline Pfirrmann score & $-0,603$ & 0,478 & $-0,033$ & Pfirrmann score & $\underline{0,841}$ & $-0,133$ & $-0,043$ \\
\hline
\end{tabular}

independently from analyzed epidemiological data (gender, orthopedic implants or region of the spine).

Although $\mathrm{Pb}$ is considered as highly toxic, it is present in every human tissue in the range $0.2-4.8 \mathrm{mg} \mathrm{kg}^{-1}$ [3]. Although the clinical syndromes with lead overdose are well known, the actual biological effect and metabolic pathway of $\mathrm{Pb}$ in the biota has not been readily analyzed. The element can influence heme synthesis by inhibiting porphobilinogen synthase and ferrochelatase. Prevention of the formation porphobilinogen iron incorporation may lead to anaemia [12]. $\mathrm{Pb}$ may behave like a calcium analog, interfering with ion channels during nerve conduction. No literature item has been identified regarding $\mathrm{Pb}$ function in connective tissue, or one resembling the IVD. The presented analysis shows the highest similarity and no competitiveness to the $\mathrm{Mg}$ and $\mathrm{Zn}$, suggesting the synergistic effects in their metabolism.

The biological role of magnesium is quite extensive. It takes part in nucleic acid chemistry with DNA and RNA synthesis, an array of enzymes require their presence as a reaction cofactor, and energetic nucleotides formation. It also plays a role in the active transport of calcium and potassium ions across cell membranes in nerve impulse conduction and muscle contraction. Most Mg ions are located intracellulary (39\%), with only $1 \%$ extracellular [13]; howver, there is no satisfactory method for assessment of its concentration [14].

Zinc, as well as Mg, is a co-factor of enzymes, DNA and protein synthesis, and is important in cell division $[15,16]$. $\mathrm{Zn}$ is believed to have antioxidative proprieties with an anti- 
aging effect and influence on the healing process [17]. It is also believed to have an effect on the immune response mechanism [18]. The most important role of the $\mathrm{Zn}$ in the IVD is probably the formation the MMPs. The element in enzyme are the co-factors that distinguish it from other ednopeptidases commonly observed both in intervertebrates and plants [19]. The role of the metaloproteinases is degradation of the extracelular matrix; its presence or over-expression is related to IVD degeneration [20]. The close relation between $\mathrm{Mg}$ and $\mathrm{Zn}$ may be in favour of the concept for simultaneous regeneration and degeneration processes taking place in IVD.

Analysis also indicates the similarity of the Cd and Mo pair. Both flora and fauna have no metabolic requirement for $\mathrm{Cd}$, although it is found in human tissue with an average content of $0.17 \mathrm{mg} \mathrm{kg}^{-1}$.

Cadmium is one of the most toxic metals for humans, mainly due to its ability to combine with sulfhydryl groups, and thus disturb the function of several enzymes that leads to changes in proteins. It has been confirmed that cadmium blocks the calcium channels in chicken neurons [21]. $\mathrm{Zn}$ deficiency can cause higher Cd storage in the human body [3], a relationship that can be observed both with graph and PCA. Cadmium is easily accumulated in animals, especially in soft tissue such as kidneys, and thus it may serve as a sensitive bio-indicator. Molybdenum is considered as an essential TE for biota, especially in the eucariotic evolutionary process responsible for stabilizing oxidised nitrogen [22]. It can bound to a number of organic molecules, such as amino-acis and carbohydrates in the form of $\mathrm{MoO}_{4}{ }^{2-}$. It takes an active part in the formation of xanthine oxidase, which is directly related to the Mo contents [23]. It can also affect protein synthesis and the metabolism of purins and fats.

In the prersented study, the least similarity was shown between $\mathrm{Cu}$ and $\mathrm{Ni}$. Beside $\mathrm{Cu}-\mathrm{Mg}$ antagonism, discussed above, antagonism was also observed between $\mathrm{Cu}$ and $\mathrm{Pb} . \mathrm{Mg}$ and $\mathrm{Pb}$, both antagonistic to $\mathrm{Cu}$, also showed similarity in this study. $\mathrm{Cu}$ is an essential element for biota. In humans, it is present in three compounds: ceruloplasmin, albumins, and amino acids [3]. Cu is found in cytochrome c oxidase, which is related with aerobic respiration where, together with iron, it plays a role in oxygen reaction. The role of metaloenzyme with $\mathrm{Cu}$ is essential in oxidation-reduction reactions and haemoglobin synthesis [24]. As the IVD is generally an avascular compartment, $\mathrm{Cu}$ compounds like ceruloplasmine and albumine should be excluded from the analysis. The range of $\mathrm{Cu}$ concentrations in human tissues is between $0.7-7.8 \mathrm{mg} \mathrm{kg}-1$, with the lowest value for muscles and the highest for liver. Mean $\mathrm{Cu}$ level in tissues of the 'reference man' is estimated at $1 \mathrm{mg} \mathrm{kg}^{-1}$ [25]. In the presented study, the range of $\mathrm{Cu}$ in the IVD tissue was from $0.97-6.089 \mathrm{mg} \mathrm{kg}^{-1}$ $\mathrm{dw}$, after stand-off measurement exclusion (23.64 $\left.\mathrm{mg} \mathrm{kg}^{-1}\right)$. The average value in the current study was 2.71 , median value $2.49 \mathrm{mg} \mathrm{kg}^{-1}$ (excluding stand-off measurement). This data has a higher value than expected, based on the above assumption. Therefore, either the data for humans or the role of $\mathrm{Cu}$ in human tissue have to be revised.

$\mathrm{Ni}$ is recognised as the oddest element in the analyzed set, suggesting the weakest bond with each of the other analyzed elements. The average Ni content in human soft tissues is estimated an average level of $88 \mu \mathrm{g} \mathrm{kg}^{-1}$ [3], although its concentrations in soft human organs vary, with the mean values being highest for bone $\left(1510 \mu \mathrm{g} \mathrm{kg}^{-1}\right)$ and lowest for the pancreas $\left(34 \mu \mathrm{g} \mathrm{kg}^{-1}\right)$. In the presented study, the the concentration ranged from $25.48-444.2 \mu \mathrm{g} \mathrm{kg}^{-1}$, with an average value of $215.3 \mu \mathrm{g} \mathrm{kg}$.

Similarity analysis for the samples did not show any significant cluster formation for given epidemiological data: gender, region of the spine of sample collection (cervical or lumbar), prior operation with metallic implants, and samples collected form the same patient. Based on this outcome, it may be concluded that with regard to the epidemiological data considered separately, it did not provide any valuable information. More information was obtained with PCA. The variability of the TE in the case of males was related to $\mathrm{Zn}$ and $\mathrm{Cu}$ concentration, which was not observed in females. Previous operation with orthopedic implants were related to the contents of $\mathrm{Al}, \mathrm{Mo}$ and $\mathrm{Zn}$, but not with such potentially toxic elements as $\mathrm{Cd}$ and $\mathrm{Pb}$. Of these elements, only $\mathrm{Mo}, \mathrm{Cr}$ or Co are used in orthopedic implants. Implants can produce a cell response, not only in close proximity, but may also may trigger a systemic response with the immune component. Although the influence of the implants are evaluated in local tissue or in blood [26], that is currently in use, to the best of the knowledge of the authors of the current study, there is no information confirming distant tissue TE alternation in such cases.

\section{CONCLUSIONS}

Chemometric analysis showed interesting dependencies among trace elements in the disc tissue, the majority of which not described in the literature. The most important are significant bonds between essential and toxic elements, as well as higher concentrations of $\mathrm{Cu}$ compared to other tissues. The presented data are the basis for further metabolic and environmental analysis of the IVD tissue.

\section{REFERENCES}

1. Holmberg S, Thelin A, Stiernström EL, Svärdsudd K. Low back pain comorbidity among male farmers and rural referents: a populationbased study. Ann Agric Environ Med. 2005; 12(2): 261-268.

2. Taher F, Essiq D, Lebl DR, Hughes AP, Sama AA, Cammisa FP, Girardi FP. Lumbar degenerative disc disease: current and future concepts of diagnosis and management. Adv Orthop. 2012; doi: $10.1155 / 2012 / 970752$.

3. Kabata-Pendias A, Mukherjee AB. Trace Elements from Soil to Human. Springer-Verlag Berlin Heidelberg, 2007.

4. Longo UG, Maffulli N, Denaro V, Petrillo S, Franceschetti E. Growth Factors and Anticatabolic Substances for Prevention and Management of Intervertebral Disc Degeneration. Stem Cells Int. 2012; doi:10.1155/2012/897183.

5. Birkedal-Hansen H, Moore WG, Bodden MK, Windsor LJ, BirkedalHansen B, DeCarlo A, Engler JA. Matrix metalloproteinases: a critival review. Oral Biol Med. 1993; 4(2):197-250.

6. Cai L, Li XK, Song Y, Cherian MG. Essentiality, toxicology and chelation therapy of zinc and copper. Curr Med Chem 2005; 12: 2753-2763.

7. Gemperline P, editor. Practical Guide To Chemometrics. 2nd ed. CRC Press(FL), 2006.

8. Brodziak B, Kwapuliński J, Bogunia M, Kropczyńska A, Orczyk H, Paukszto A, Nogaj E. The Occurrence of Co, Ag, Al, Sr in Femur Head. Polish J Environ Stud. 2006; 15: 20-22.

9. Tohno S, Tohno Y, Minami T, Ichii M, Okazaki Y, Utsumi M, Nishiwaki F, Yamada M. Difference of mineral contents in human intervertebral disks and its age-related change. Biol Trace Elem Res. 1996; 52(2):117124.

10. Minami T, Hashii K, Tateyama I, Kadota E, Tohno Y, Tohno S, Utsumi M, Yamado MO, Ichii M, Namikawa K, et al. Accumulation of platinum in the intervertebral discs and vertebrae of ovarian tumor-bearing patients treated with cisplatin. Biol Trace Elem Res. 1994; 42(3): 253-257. 
11. Pfirrmann CW, Metzdorf A, Zanetti M, Hodler J, Boos N. Magnetic resonance classification of lumbar intervertebral disc degeneration. Spine. 2001; 26(17): 1873-1878.

12. Cohen AR, Trotzky MS, Pincus D. Reassessment of the Microcytic Anemia of Lead Poisoning. Pediatrics. 1981; 67(6): 904-906.

13. Rude RK. Magnesium. In: Ross AC, Caballero B, Cousins RJ, Tucker KL, Ziegler TR, (eds.) Modern Nutrition in Health and Disease, 11th ed. Lippincott Williams \& Wilkins; Baltimore 2012. p.159-175.

14. Witkowski M, Hubert J, Mazur A. Methods of assessment of magnesium status in humans: a systematic review. Magnesium Res. 2011; 24: $163-$ 180 .

15. Dietary Reference Intakes for Vitamin A, Vitamin K, Arsenic, Boron, Chromium, Copper, Iodine, Iron, Manganese, Molybdenum, Nickel, Silicon, Vanadium, and Zinc. Washington (D.C.) National Academy Press, 2002.

16. Prasad AS. Zinc: an overview. Nutrition. 1995; 11: 93-99.

17. Milbury, Paul E, Richer, Alice C. Understanding the Antioxidant Controversy. Wesport (CT) Greenwood Publishing Group. 2008.

18. Keen CL, Gershwin ME. Zinc deficiency and immune function. Annu Rev Nutr. 1990; 10: 415-431. doi:10.1146/annurev.nu.10.070190.002215.

19. Gross J, Lapiere CM. Collagenolytic activity in amphibian tissues: a tissue culture assay. Proc Natl Acad Sci. USA. 1962; 48: 1014-1022.
20. Van Lint P, Libert C. Chemokine and cytokine processing by matrix metalloproteinases and its effect on leukocyte migration and inflammation. J Leukoc Biol. 2007; 82(6): 1375-1381. doi:10.1189/ jlb.0607338.

21. Swandulla D, Armstrong CM. Calcium channel block by cadmium in chicken sensory neurons. Proc Natl Acad Sci. 1989. 86 (5): 1736-1740. doi:10.1073/pnas.86.5.1736.

22. Scott C, Lyons TW, Bekker A, Shen Y, Poulton SW, Chu X, Anbar AD. Tracing the stepwise oxygenation of the Proterozoic ocean. Nature. 2008; 452(7186): 456-459. doi: 10.1038/nature06811.

23. Emsley J. Nature's Building Blocks. Oxford: Oxford (UK) Oxford University Press, 2011.

24. Lippard SJ, Berg JM. Principles of bioinorganic chemistry. Mill Valley (CA) University Science Books, 1994.

25. Li Y-H. A compendium of geochemistry: from solar nebula to the human brain. Princeton (NJ) Princeton Univ Press, 2000.

26. Kretzer JP, Reinders J, Sonntag R, Hagmann S, Streit M, Jeager S, Moradi B. Wear in total knee arthroplasty-just a question of polyethylene?: Metal ion release in total knee arthroplasty. Int Orthop. 2013; 12 [Epub ahead of print]. 